\title{
Lágyéksérvet utánzó gigantikus méretü myxoid leiomyoma
}

\author{
Huszár Orsolya dr. ${ }^{1}$ - Zaránd Attila dr. ${ }^{1}$ - Szántó Gyöngyi dr. ${ }^{4}$ \\ Juhász Viktória dr. ${ }^{1}$. Székely Eszter dr. ${ }^{2}$ - Novák András dr. ${ }^{3}$ \\ Molnár Béla Ákos dr. ${ }^{1}$ - Harsányi László dr. ${ }^{1}$ \\ Semmelweis Egyetem, Általános Orvostudományi Kar, \\ ${ }^{1}$ I. Sebészeti Klinika, ${ }^{2}$ II. Patológiai Intézet, ${ }^{3}$ II. Sebészeti Klinika, Budapest \\ ${ }^{4}$ Nanomed Bt., Budapest
}

\begin{abstract}
A leiomyoma a simaizom ritka, jóindulatú daganata, amely előfordulhat bárhol az emberi szervezetben. A szerzők 60 éves nőbeteg kórtörténetét ismertetik, akinél a lágyékhajlatban gigantikus méretű, Müller-cső-eredetû́ myxoid leiomyoma keltette akut hasi kórkép gyanúját. A kivizsgálást követően jobb oldalon femoralisan, fekvő helyzetben a lábszár középső harmadáig lelógó, legnagyobb kiterjedésében $335 \times 495 \times 437$ mm nagyságú, 33 kg súlyú tumoros elváltozást távolítottak el, majd a szövethiányt az onkoplasztikai alapelveknek megfelelően rekonstruálták. Utánkövetés során tumorrecidíva nem igazolódott és a beteg életminősége jelentősen javult. Orv. Hetil., 2016, 157(10), 392-395.
\end{abstract}

Kulcsszavak: myxoid leiomyoma, inguinalis sérv, óriás lágyrész-tumor, onkoplasztika

\section{A giant myxoid leiomyoma mimicking an inguinal hernia}

\begin{abstract}
Leiomyoma is a rare, smooth muscle tumour that can occur everywhere in the human body. The authors present the history of a 60-year-old female, who had a giant, Mullerian type myxoid leiomyoma in the inguinal region mimicking acute abdominal symptoms. After examination the authors removed the soft tissue mass in the right femoral region reaching down in supine position to the middle third of the leg measuring $335 \times 495 \times 437 \mathrm{~mm}$ in greatest diameters in weight $33 \mathrm{~kg}$. Reconstruction of the tissue defect was performed using oncoplastic guidelines. During the followup time no tumour recurrence was detected and the quality of life of the patient improved significantly.
\end{abstract}

Keywords: myxoid leiomyoma, inguinal hernia, giant soft tissue mass, oncoplasty

Huszár O., Zaránd A., Szántó, Gy., Jubász, V., Székely, E., Novák, A., Molnár, B. Á., Harsányi, L. [A giant myxoid leiomyoma mimicking an inguinal hernia]. Orv. Hetil., 2016, 157(10), 392-395.

(Beérkezett: 2015. december 8.; elfogadva: 2016. január 12.)

$\mathrm{Az}$ inguinofemoralis régióban elhelyezkedő térfoglaló folyamatok komoly differenciáldiagnosztikai nehézséget jelenthetnek. Az elváltozások hátterében állhat lágyéksérv, femoralis sérv, nyirokcsomó-elváltozás, endometriosis, lipoma, haematoma, tályog, neurofibroma, desmoid tumor, arteria femoralis aneurysma, fibroid méhelváltozás, vena saphena magna thrombophlebitis, metasztázis, dermoid és epidermoid cysta, valamint simaizom-eredetű tumor is [1].

\section{Esetismertetés}

Hatvanéves, kifejezetten túlsúlyos (BMI: 45,54, 127 kg, $167 \mathrm{~cm}$ ) nőbeteg gyenge általános állapotban, nyugalmi dyspnoéval jelentkezett családorvosánál, majd jobb oldali kizárt lágyéksérv gyanúja miatt került sebészeti ambulanciánkra. Fizikális vizsgálata során a beteg által már 15 éve hordozott, bizonytalan kiindulású és dignitású jobb oldali lágyrész-elváltozást találtunk, amellyel még nem 
fordult orvoshoz (1.ábra). A beteg elmondása szerint a lágyékhajlatban található duzzanat a megelőző három hétben hirtelen jelentős növekedést mutatott, míg korábban lassú méretváltozás volt rá jellemző.

Laboratóriumi leleteiben emelkedett C-reaktív protein értéket, illetve kifejezett anaemiát találtunk. Heveny hasi katasztrófa biztonsággal kizárható volt, ezért első ellátásként két egység vörösvértestmassza szövődménymentes transzfúziójában részesült. Vérképének rendezése után sürgős hasi CT-vizsgálata jobb oldalon parailiacalisan és inguinalisan megnagyobbodott nyirokcsomókat, illetve a jobb oldalon femoralisan, fekvő helyzetben a lábszár középső harmadáig lelógó, legnagyobb kiterjedésében $335 \times 495 \times 437$ mm nagyságú, kissé inhomogén, hypodens terimét igazolt, amelyben több apró meszesedés és kontrasztanyagot halmozó septumok voltak láthatók. Az elváltozás kifejezett vascularisatiót mutatott, amelyet a vena femoralis és az arteria iliaca externa biztosított (2. ábra). Mellékleletként több nagyobb myomagöböt tartalmazó uterust és a bal oldali mellékvesé-

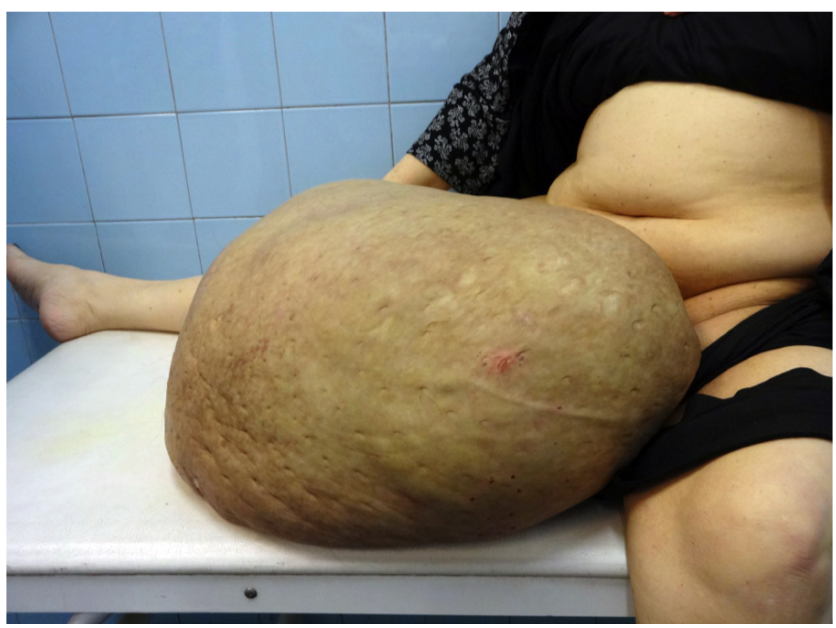

1. ábra $\quad$ Az inguinofemoralis elváltozás képe az első fizikális vizsgálatkor

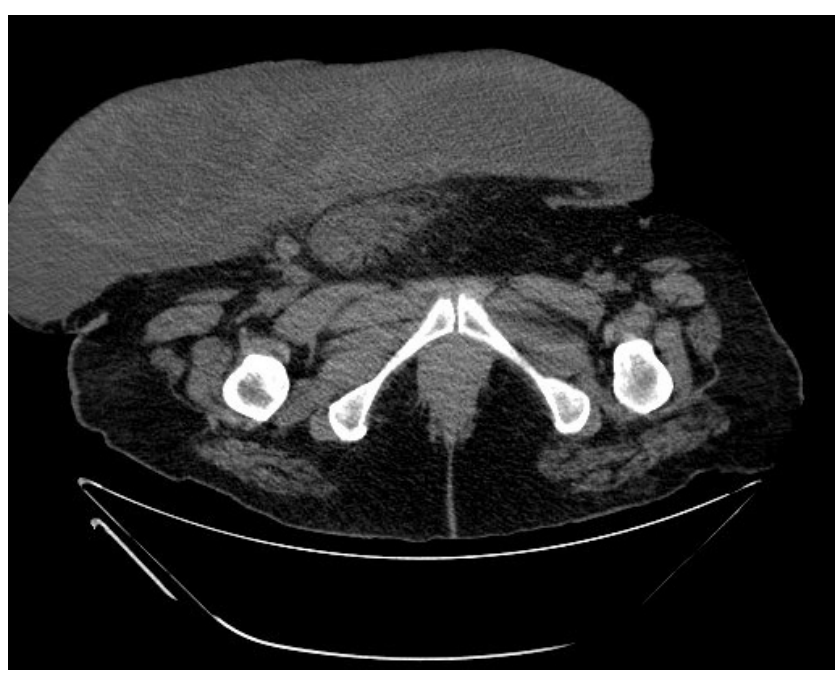

2. ábra $\quad$ A CT-felvételen kissé inhomogén, hypodens terime állományán belül kontrasztanyagot halmozó septumok láthatók

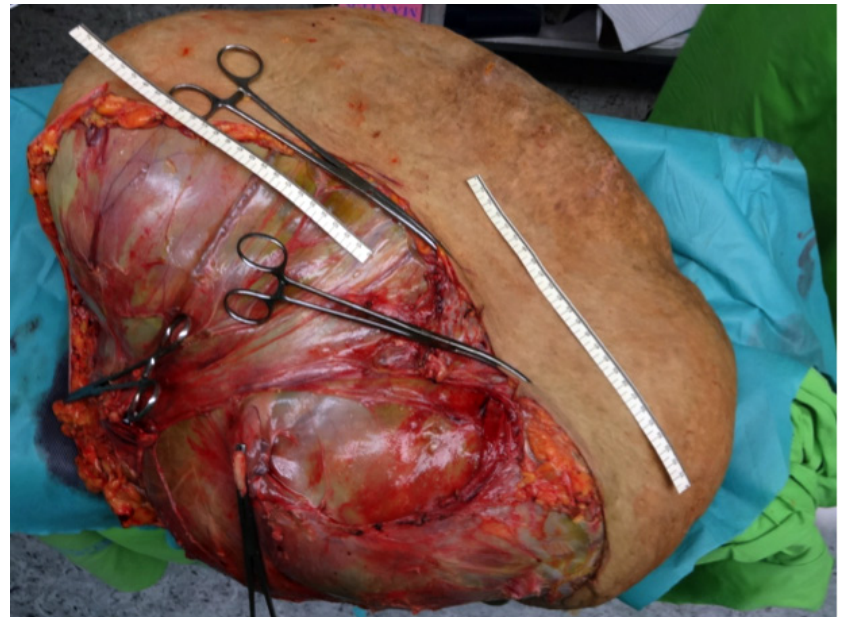

3. ábra $\mid$ Intraoperatív kép az eltávolított mútéti preparátumról

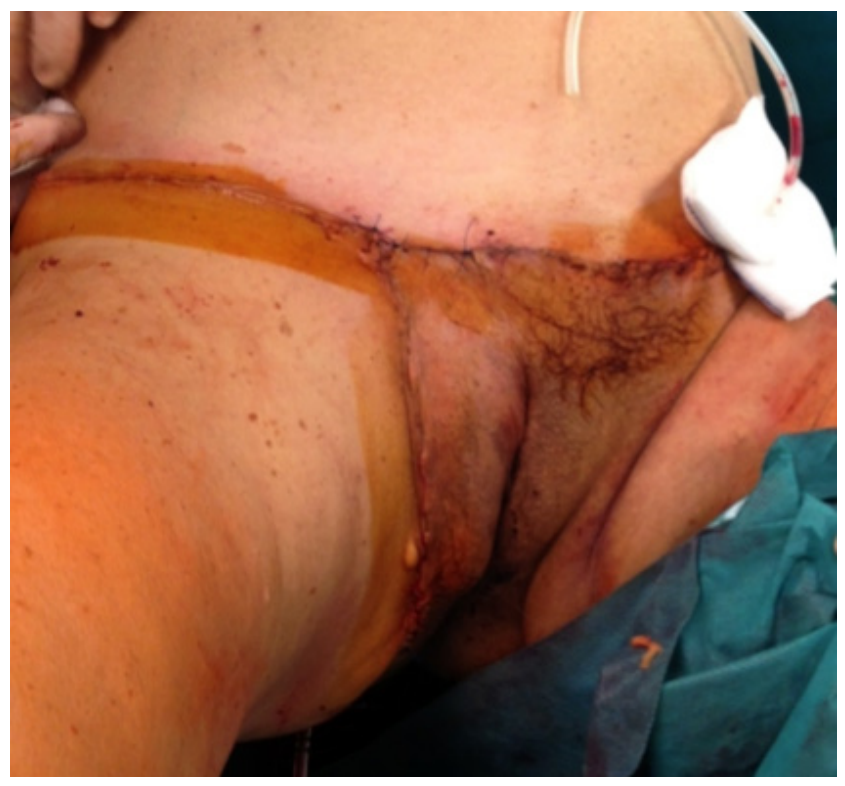

4. ábra | Rekonstrukció utáni állapot („lower body lifting” metszésvonalai)

ben térfoglalást is leírtak. Az elsődleges radiológiai vélemény az elváltozást extrém méretű femoralis sérvnek minősítette. A lágyrész-folyamat mérete miatt egyébként indokolt kismedencei MR-vizsgálatot technikai okokból nem tudtuk kivitelezni: a páciens nem fért be a vizsgálóberendezésbe.

A beteg a tumor mérete miatt évek óta ágyhoz kötött életet élt, lakását sem hagyta el. Nőgyógyászati konzílium véleménye alapján az elváltozás a nőgyógyászati szervekkel szoros összefüggésben nincs, ugyanakkor a daganatos méh eltávolítását indokoltnak tartották.

Előkészítést követően antibiotikum- és thrombosisvédelemben mútétet végeztünk, amely során a ligamentum rotundumból kiinduló, peritonealis nyúlványt nem tartalmazó lágyrész-tumort találtunk (3. ábra). A 33 kg-os elváltozást exstirpáltuk. A szövethiány korrekcióját a plasztikai sebészetben használt alsó testkontúr javításakor (lower body lift) alkalmazott metszéseknek megfele- 
lően végeztük, majd a sebet több rétegben zártuk (4. ábra). A kórszövettani vizsgálat alapján az elváltozás myxoid leiomyomának bizonyult, malignitásra utaló hisztológiai eltérés nem igazolódott. A kiegészítő immunhisztokémiai eredmények alapján S-100-negatív, Ki67 1\%-ban pozitív, p53-negatív, illetve ösztrogénpozitív és WT1-pozitív volt, amely alapján a daganatot Müller-cső-eredetưnek véleményezték. A posztoperatív időszak eseménytelenül zajlott, a beteg a mütétet követő nyolcadik napon, reakciómentes sebbel távozott intézetünkből.

\section{Megbeszélés}

A leiomyoma a simaizomból kiinduló jóindulatú daganat, amelyet elóször Virchow írt le 1854-ben [2]. Leggyakrabban a méhben jelentkezik, de a szervezetben bárhol előfordulhat. Esetünkben egy ritka típusú és megjelenésű formáját ismertetjük, amely ösztrogénreceptor-pozitív, úgynevezett Müller-cső-eredetű leiomyoma vagy „parazita” leiomyoma. A parazita jelző arra utal, hogy feltételezések szerint ez a tumor kezdetben a méhvel lehetett összeköttetésben, majd később levált róla. Mivel ez a teória teljességgel nem bizonyított, inkább peritonealis eredetû, hormonszenzitív simaizomtumorról beszélhetünk [3]. Ilyen típusú tumorok előfordulhatnak a retroperitoneumban, ahol nagy méreteket ölthetnek, de máshol is a szervezetben, például a peritoneumon, a csepleszen, mesenteriumon, belek között vagy intestinalis lokalizációban is. Az inguinalis régióban nőkben előforduló, ilyen típusú tumorok nagy valószínúséggel a ligamentum rotondumból származnak, kétharmaduk extraperitonealis és legtöbbször jobb oldali megjelenésüek $[4,5]$. A ligamentum rotundum az uterusból ered, majd a canalis inguinalison átívelve a mons pubison, illetve az azonos oldali nagyajkakban végződik. Simaizomrostokból, kötőszövetből, erekből és mesothelialis borítású idegekből épül fel [4]. Ebből kialakuló primer tumorok előfordulása nagyon ritka, mégis a gyakoribbak közé tartozik a leiomyoma, endometriosis, mesothelialis cysta [6]. Ritkábban előfordulhat myolipoma, lipoma, dermoid cysta, haemangioma, nodularis fascitis, perivascularis epitheloid sejtes tumor (PEComa) [7].

A klinikumban használt képalkotó vizsgálatok (elsősorban CT) segítségünkre lehetnek, hiszen az elváltozás a felvételeken általában karakterisztikus megjelenést mutat. CT-képeken jól körülhatárolt, heterogén, denz massza látható [4]. A myxoid leiomyoma esetében az MR-felvétel akár diagnosztikus is lehet, hiszen a myxoid elemek a T2-felvételeken magas intenzitású, míg T1-felvételen alacsony intenzitású képet adnak [8].

Az irodalmi adatokat átnézve ebben a régióban észlelt, közölt leiomyoma mérete változó, lehet akár egészen kisméretü, 1,8 cm-es, de leírtak $26 \mathrm{~cm}$-es tumort is $[4,9]$. A ligamentum rotundum ösztrogén- és progesz- teronreceptorokat expresszál, amelynek következtében az itt megjelenő tumorok általában hormonszenzitívek [7]. Ezzel magyarázható az is, hogy az itt megjelenő leiomyomák többsége középkorú hölgyeknél, preamenopausalisan jelentkezik [4].

Müller-cső-eredetű leiomyoma esetében az immunhisztokémiai vizsgálatok pozitív eredményt adnak SMA, desmin, caldesmon, ösztrogén, progeszteron és Wilmstumor-fehérje (WT1) kimutatása esetében [3]. Betegünknél ösztrogén- és WTl-pozitivitás volt kimutatható. A myxoid leiomyomákat fontos elkülöníteni malignus formájától, amelyben segíthet a tumor mérete, a tumorhatár jellege, illetve a vascularis invázió hiánya vagy jelenléte, továbbá a mitoticus aktivitás, sejtatípia és nekrózis mértéke $[4,10]$. A metszeti felszín makroszkópos megjelenésében azonban nagy különbség nem fedezhető fel: mindkettő puha, szürkés színű, kocsonyás állagú, gyakran jól körülhatárolt [10]. A nagyméretû myxoid leiomyomák gyakran klinikailag malignusan viselkednek, annak ellenére, hogy a sarcoma diagnosztikus kritériumait nem teljesítik [11]. A simaizomtumorok közül az ösztrogén- és WTl-pozitív Müller-cső-eredetű tumorok prognózisa a méhben található leiomyomákhoz hasonlóan jó, ellentétben az ER/WTl negatív leiomyosarcomákkal [9].

A simaizom ilyen típusú tumorainak kezelésére gyökeres helyi kimetszés ajánlott, akár recidíva esetén is [12]. A tumor mérete okán a beavatkozást az onkoplasztika irányelveinek megfelelően végeztük, ennek során az onkológiai mútéteknél is elvárható, hogy olyan, a plasztikai sebészetben is alkalmazott esztétikai vagy rekonstrukciós mútéttechnikákat alkalmazzunk, amelyek a beteg életminőségét javítják, és funkcionális, esztétikai eredményt adnak. Így betegünknél a tumor onkológiai szempontból radikális kimetszésre került, majd a keletkezett szövethiányt a plasztikai sebészetben ismert módszerrel, azaz az esetismertetésben is említett „lower body lifting” metszésirányai segítségével korrigáltuk. Ezt általában a nagymértékben megereszkedett bőrszövet eltávolításakor, a hasplasztika és combplasztika metszéseinek összekötésével végezzük a plasztikai és rekonstrukciós sebészetben.

Kétéves utánkövetésünk során tumorrecidíva nem volt igazolható és a beteg életminősége jelentősen javult.

\section{Következtetés}

Esetünkben riasztó méretű, akut hasi kórképet utánzó állapot hátterében egy benignus, ritka előfordulású simaizom-eredetû tumor állt. A daganat eltávolítása önmagában mérete miatt jelentett kihívást, és megoldása onkoplasztikai felkészültséget igényelt. Fontos a szövettani differenciáldiagnózis a prognózis elbírálásához, amelyhez elengedhetetlen az immunhisztokémiai vizsgálatok elvégzése. 
Anyagi támogatás: A közlemény megírása anyagi támogatásban nem részesült.

Szerzői munkamegosztás: H. O.: A kézirat megírása, a mütét részelemének operálása. Z. A.: Betegfelvétel, a kézirat lektorálása. Sz. Gy.: A beteg észlelése, kivizsgálása. J. V.: Betegfelvétel, mütéti asszisztencia. Sz. E.: Kórszövettani vizsgálat, elemzés. N. A.: Mütéti asszisztencia. M. B. Á.: Mütéti tervezés. H. L.: Operatőr, a kézirat lektorálása. A közlemény végleges változatát a szerzők elolvasták, és jóváhagyták.

Érdekeltségek: A szerzőknek nincsenek érdekeltségeik.

\section{Irodalom}

[1] Colak, E., Ozlem, N., Kesmer, S., et al.: A rare inguinal mass: round ligament leiomyoma. Int. J. Surg. Case Rep., 2013, 4(7), 577-578.

[2] Von Virchow, R.: Ueber Makroglossie und pathologische Neubildung quergestreifter Muskelfasern. Virchows Arch. Pathol. Anat., 1854, 7, 126-138.

[3] Miettinen, M.: Smooth muscle tumors of soft tissue and nonuterine viscera: biology and prognosis. Mod. Pathol., 2014, 27, S17-S29.

[4] Ali, S. M., Malik, K. A., Al-Qadhi, H., et al.: Leiomyoma of the round ligament of the uterus: case report and review of literature. Sultan Qaboos Univ. Med. J., 2012, 12(3), 357-359.
[5] Chang, T. M., Tsui, K. H., Cheng, J. T., et al.: Chronic pelvic pain secondary to leiomyoma of the round ligament. Taiwan. J. Obstet. Gynecol., 2013, 52(1), 135-136.

[6] Breen, J. L., Nenbecker, R. D.: Tumors of the round ligament. A review of the literature and a report of 25 cases. Obstet. Gynecol., 1962, 19(6), 771-880.

[7] Pattamapaspong, N., Khunamornpong, S., Phongnarisorn, C., et al.: Malignant perivascular epithelioid cell tumour of the round ligament mimics leiomyoma on computed tomography. Singapore Med. J., 2009, 50(7), e239-e242.

[8] Aggarwal, B. K., Panwar, S., Rajan, S., et al.: Varied appearances and signal characteristics of leiomyomas on $\mathrm{MR}$ imaging. Indian J. Radiol. Imaging, 2005, 15(2), 271-276.

[9] Patil, D. T., Laskin, W. B., Fetsch, J. F., et al.: Inguinal smooth muscle tumors in women-a dichotomous group consisting of Müllerian-type leiomyomas and soft tissue leimyosarcomas: an analysis of 55 cases. Am. J. Surg. Pathol., 2011, 35(3), 315-324.

[10] Manjula, K., Rao, K. S., Chandrasekhar, H. R.: Variant of leiomyoma: histomorphological study of tumors of myometrium. J. SAFOG, 2011, 3(2), 89-92.

[11] Ueda, H., Togashi, K., Konishi, I., et al.: Unusual appearances of uterine leiomyomas: MR imaging findings and their histopathologic backgrounds. Radiographics, 1999, 19(Suppl. 1), S131S145.

[12] Tavassoli, F. A., Norris, H. J.: Smooth muscle tumors of the vulva. Obstet. Gynecol., 1979, 53(2), 213-217.

(Huszár Orsolya dr., Budapest, Üllői út 78., 1082 e-mail: o.huszar@gmail.com)

\section{A rendezvények és kongresszusok híranyagának leadása}

a lap megjelenése előtt legalább 40 nappal lehetséges, a 6 hetes nyomdai átfutás miatt. Kérjük megrendelőink szíves megértését.

A híranyagokat a következő címre kérjük:

Orvosi Hetilap titkársága: Budai.Edit@akkrt.hu

Akadémiai Kiadó Zrt. 